\title{
Third-Space Encounters and Unexpected Forms of Resistance in Amy Tan's The Joy Luck Club
}

\author{
Abbasali Borhan ${ }^{1, a^{*}}$ and Alireza Anushiravani ${ }^{2, b}$ \\ ${ }^{1} \mathrm{PhD}$ Candidate in English Literature, Shiraz University, I. R. Iran \\ ${ }^{2}$ Professor of English \& Comparative Literature, College of Literature \& Humanities, \\ Shiraz University, I. R. Iran \\ aa.borhan@yahoo.com, banushir@shirazu.ac.ir \\ ${ }^{*}$ Corresponding Author: Abbasali Borhan
}

Keywords: Amy Tan, The Joy Luck Club, Chinese-American, third-space, Orientalism, resistance.

\begin{abstract}
This paper sets out to investigate Amy Tan's The Joy Luck Club, a liminal work written in-between cultures, in the light of Homi Bhabha's concept of the third space as a site of transformation and transvaluation. It is argued that Tan's novel is implicated in unexpected forms of resistance as a result of its placement in the borderland of cultures. Thus, exploring the discursive fissures and ideological ruptures inscribed in the novel, the authors seek to bring to fore how the very mainstream accounts of Chinese culture and orientalist archive of knowledge in which the work is embedded are contested in the third-space enounters between subjects of different cultures. Orientalism, Western feminism, American Dream, and multiculturalism are some of the major discourses whose truthfulness and serenity are shown to be precarious and open to questioning, hence the recuperation of the subaltern's voice through this contrapuntal reading.
\end{abstract}

\section{INTRODUCTION}

In a world haunted by the specter of terror, discursively identified as the language of "others," it is not superfluous to emphasize the importance and necessity of contesting the prevalent xenophobic and totalizing accounts of authorized "sameness" and of recuperating the voice of the feared "subaltern" as implicated in multi-ethnic literatures of the US. The study of literatures produced and received in the borderlands, the third space of enunciation, brings to fore the exclusionary procedures and regulatory mechanisms governing cultures in general, and the resultant rationalizations of hierarchical structures of relations negotiated and maintained through essentialized differences between "us" (Americans) and "them" (ethnic Americans or mixed Orientals), in particular. This article advances that Amy Tan's very positioning in between cultures renders her claims on truthfulness of the authorized statements and orientalist re-inscriptions ambivalent. Thus, it is maintained that there is an excellent potential in Tan's The Joy Luck Club (1989) [21] for the postcolonial critic to deploy in a contrapuntal reading of the discursive ruptures occurring in the third-space encounters of essentialisms and as such to challenge and unsettle the established structures of meaning built upon master narratives of identification such as (neo)Orientalism, multiculturalism, feminism, minority model, and globalization. In so doing, Bhabha's conception of hybridity [4], a critical tool capable of misplacing and problematizing "naturalized" boundaries, is taken as a point of departure for firstly, exposing the untenability of us/them essentialisms of relations as portrayed in the novel set in the contemporary American society and secondly, foregrounding the possibility of recovering subaltern's voice.

\subsection{Literature Review}

Harold Bloom, in his brief introduction to Amy Tan, quotes a symbolic passage from the novel, The Joy Luck Club, in which the American-born daughter and her Chinese mother are fiercely involved in a cultural conflict over their opposing world-views and manners [6, p. 2]. Representative of two cultures, American and Chinese, as hinted in Bloom's reading, June and Suyuan fit well into the stereotypical binary oppositions established between Americanness and Chineseness: individual/mass, autonomy/dependence, freedom/tyranny, modern/tradition, 
speech/silence, rebellion/ submission, literate/illiterate, etc. Bloom's selection of an excerpt from the novel in which most of the binary oppositions aforementioned are inscribed illuminates the crucial functioning of the author within the authorized discourses of representation in this genre. And perhaps that is why it receives credit from Bloom as being marked for its "power of simplicity and of universality" [6, p. 2]. The "universality" in Bloom's words is a highly charged and contested term as it is predicated upon such propositions as "totalizing globalism," in Simon During's terminology [12, p. 87], which serve to render the differences null and void, hence measuring them against the accepted (canonical) norms defined by the dominant culture within which they are produced. Bloom further notes that the images Tan gives in this passage are very "much Homeric and Virgilian as Chinese," thus pointing out to the text being a "universal" one with which even Bloom himself can identify, reminiscing about "acquaintances of [his] own childhood, in the later 1930s in the east Bronx, who suffered agonies of enforced violin lessons, as though each one of them could revive the musical tradition of Jewish Odessa" [6, p. 2]. Interestingly enough, the movie adaptation of the novel also, which as Jing Yin puts it, made Tan "an overnight celebrity" with "two-million-copy book sale" in early 1990s, was applauded for the same claim of "universal" quality $[24$, p. 150]. She observes that what binds all such laudatory reviews is their underlying preposition that "Asians or Asian Americans are not 'human and universal' until they become acceptable to the mainstream. ... Thus, the claim of universality works as a mechanism of exclusion that perpetuates existing social hierarchies and power structures" [24, p. 150].

Another important point to note about Bloom's brief commentary is the way he fashions Tan along with her equally popular predecessor, Maxine Hong Kingston, as a model minority writer to be emulated by the future "ephebes," in his own jargon [7, p. 83]. He maintains: "whatever the future course of her work will be, she at least has joined Maxine Hong Kingston in breaking a new road, doubtless at considerable inner cost" $[6, p .2]$. By the same token, some other critics have heaped similar praise on the writer's adept exploration of Chinese culture as being essentially at odds with and inferior to American one, hence their mutually-exclusive oppositional relationship. To illustrate the shared "structure of attitudes and reference," in Said's words [20, p. 69], which binds together most of such celebratory readings, it is worth quoting a paragraph from one of the earliest receptions of the text by Orville Schell. Reducing the whole story, in similar fashion as Bloom does, to the intergenerational conflicts of the American-born assimilated daughter and her nativist Chinese mother, Schell asserts: "she is made uncomfortable by the older generation's insistence on maintaining old customs and parochial habits, which she views as an impediment to breaking loose from her parents' cultural gravity. What she yearns for is to lead an independent, modern and American life free of the burden of her parents' Chineseness" [19]. It is somewhat eerie as to how similar these two receptions of the novel tend to be from popular and academic standpoints, both relying on such presuppositions as Chinese backwardness and subjugation as opposed to American modernity and freedom. Deeming the story "a jewel of a book," Schell also concludes his review by fashioning a model out of it [19]. More revealing is the way he uses a precious commodity, jewel, to hail Tan's novel, which likewise is to be sold and consumed only because of its commodification of difference as authorized by the dominant discourses in which it is placed. This issue is widely addressed by the critics who find the book catering to the publishers' taste and contributing to consumerist reification of minority literatures valued only for their tag of a neutralized difference. In this regard, Yongsuk Chae appositely remarks that

If racial/ethnic writers are obliged by publishers to highlight cultural differences to the point that the difference becomes essentialized and theatricalized as "exotic" cultural otherness, these writings in a way have paid for the "partial admission" of minority writers to the mainstream literary markets by commodifying cultural differences and ethnic values. [8, p. 33]

Cultural differences, in this view, are exoticized into sellable commodities to be passively consumed just like any other goods in the capitalist market. "Thematic ghettoization" is the term Françoise Kral uses to describe this neutralizing reductionism as exerted upon minority writers who aspire to have their works published in American society [15, p. 21]. She maintains that by having the writers address certain favorable issues as minorities in their works, publishers have effectively 
"dispossessed" these writers of their "autonomous choice with respect to aesthetic matters" [15, p. 21]. In other words, this is the publishing market, itself functioning within the broader discourses dominating the society, that determine even the kinds of themes to be addressed in ethnic literatures. Interestingly enough, it is against the same backdrop of tensions between aspirant ethnic writer and domineering American publisher that Tan gets to publish her novel in the first place. The title Tan had chosen for her book was Wind and Water, but it was changed into the eye-catching phrase Joy Luck Club by the perceptive publisher [10, p. 62] so that the cultural difference would be foregrounded and better exoticized. On the one hand, the very word Club effectively conjures up the notorious Chinese clubs and slums in which "joy" and "luck" are turned into commodities in the form of a Chinese game: mahjong, a dominant image with a wide variety of implications attached to it such as trickiness, deception, cunning, etc. On the other hand, the phrase itself seems to be in want of something for it to be grammatically correct and semantically meaningful. That is to say, as an exoticized cultural item, it is only partially familiar (true), owing to its replication of the dominant codes of signification, but still, being different, it contains some errors which render it distinctively "different." Thus, even the title of the book is filtered through exotic fetishism as an instance of exclusionary procedures exerted upon cultural products of minority groups.

Studying the problems of language as addressed in Chinese-American writings, Emma J. Teng [22] points out another less noticeable aspect of exotic fetishism as consciously exercised by the authors in their (mis)use of Chinese language as an unbridgeable gap between older generations and the American-born children. In passing, Teng [22] contends that Chinese transliteration of certain words in Tan's Joy, for instance, are used to further exoticize the linguistic difference by making it sound incomprehensible to anyone outside the community of Chinese speakers. She says:

Unlike the earlier attempts to write Chinatown English, which were intended to be "faithful" renderings of how people actually speak, the main function of this type of code switching is to signify difference, Chineseness. This practice is controversial, and, like Kingston, Tan has been criticized for exoticizing her work. [23, p. 67]

Elaborating on the dynamics involved in commodification of cultural difference, particularly in postcolonialist field, Graham Huggan holds that as a "mode of aesthetic perception," exoticism is not an "inherent" quality to be detected in the minority works, it rather operates on a dialectical level, serving both to make the "other" look strange and at the same time to familiarize it in the eyes of the perceiver so that it could be co-opted [14, p. 13]. Huggan's argument is very much in line with Bhabha's idea about the ambivalent nature of all stereotyping apparatus deployed in cultural encounters between the colonizer and the colonized. In Bhabha's view, this paradoxical desire to identify and disavow the difference as perceived in the "other" leaves some room for gazing back and unsettling the fixated power relations established between us and them [4]. He contends that 'the fetish or stereotype gives access to an 'identity' which is predicated as much on mastery and pleasure as it is on anxiety and defense, for it is a form of multiple and contradictory belief in its recognition of difference and disavowal of it" [4, pp. 74-75]. This being the case, one can even assert that works such as Tan's Joy, which are criticized for their reproducing and further exoticizing Chinese culture, may better lend themselves to critical analysis of the workings of dominant discourses in containing the potential power of the subaltern to act as the subject of enunciation.

To take up where Bloom left, it merits contemplating his concluding words about Tan's paying a huge price, or as he puts it, "considerable inner cost," [6, p. 2] for garnering both popular and also critical acclaim among the American readership. Inner, because unlike the welcome reception she enjoyed with American mainstream media, Tan has been faced with strong criticism from her fellow Chinese writers and critics. Frank Chin, most vocal of all, considers her as following in the footsteps of the early Chinese-American autobiographers who adopted an apologetic stance in their attempted rationalization of Chinese foreignness in the eyes of the American readership [1, p. 122]. These authors, Chin argues, are complicit in perpetuating such discursive themes as Chinese inferiority, exoticism, backwardness, and the like, hence amassing a "fake" literature about Chinese-American experience [1, p. 122]. About Tan's reworking of Chinese 
myths and fairy tales in her Joy, Chin notices that they are "fake" stories fashioned by the writer to please the American taste. The vignette opening the novel, for instance, Chin argues, is "not Chinese but white racist. It is not informed by any Chinese intelligence" [11, p. 131]. The criticism of Tan's neo-Orientalism is not limited to the "inner" sphere, however, it includes those coming from outside Chinese community too. Bella Adams, for instance, criticizes Tan for her reinscription of Orientalist stereotypes in Joy. Analyzing one of the many instances of cultural conflicts depicted between daughters and mothers in the novel, she notes that "essentialism is a focus of The Joy Luck Club but, crucially, not its telos" [1, p. 126].

Of course, not all Chinese-American writers are critical of Tan's works. In her study of Tan, Susan Muadi Darraj, speaks highly of the writer and her self-conscious distancing from "any type of ethnic" labels and her preferring to be called "American writer" rather than "Chinese-American" [10, p. 66]. Darraj, relying on the myth of American multiculturalism, deems Tan as representing "what the United States itself represents: the idea that a country can embrace people of all nationalities, religions, and backgrounds under one flag" [10, p. 66]. Darraj also quotes Tan's response to the criticism leveled against her unfavorable representation of Chinese culture: "I can only suppose that if writers were responsible for people's thoughts and for creating positive role models, we would then be in the business of writing propaganda, not art as fiction. Fiction makes you think; propaganda tells you how to think" [10, p. 67]. That Tan refrains from sanitizing the Chinese culture is one point, but her veering toward replication of certain Chinese stereotypes is a totally different thing. Nevertheless, as earlier mentioned, every account of cultural encounters is marked with ideological gaps and fissures, and this is in these moments of uncertainty that the unwelcome truths may be cut loose. In the following sections, some of these discursive fractures are addressed.

\section{DISCUSSION}

The subject of studies in world literature, Bhabha argues, should be "the study of the way in which cultures recognize themselves through their projections of 'otherness" [5, p. 146]. Elaborating on this point, he further adds that "the center of such a study would neither be the 'sovereignty' of national cultures, nor the 'universalism' of human culture, but a focus on those "freak displacements"' [5, p. 145]. This kind of displacement, however, is particularly addressed in multi-ethnic literatures wherein writers of "subaltern" descents, themselves located in cross-cultural zones of enunciation, register epistemological as well as ontological indeterminacies and uncertainties undertaken by subjects situated within the third space, as a site of (re)fashioning, (re)construction, and transformation. The transformative power of this borderland, it is asserted, though not always rewarding and empowering for the subject engaged with it, brings to fore the mechanisms governing cultures based on hierarchical rationalizations of us/them structures of relations as enunciated, authorized, naturalized, and mythologized through dominant discourses and grand narratives of identification. (Neo-)Orientalism, American Dream, the Promised Land, multiculturalism, universal woman (as advocated in western feminism), and ethnic minority model, among others, are some of the major narratives contested and demythologized through third-space encounters inscribed in the writings produced by American authors of Oriental descent. To substantiate this point, in what follows, ample evidence is provided from Tan's novel, The Joy Luck Club.

\subsection{The Plucked Swans: Disillusioned Mothers.}

Despite its deceptively simple retelling of a folklore-like tale, the opening vignette of the novel contains illuminating critical undertones of such overwhelming myths as American Dream, Promised Land, and Multiculturalism. That this short tale has received scanty attention might be due to its seemingly marginal position ("parergon" in Derridian sense) in the unfolding of the events of the story. The nameless woman character in this tale re-narrates the story of her embarking upon a journey across Pacific Ocean, fraught with glittering promises and hopes which eventually turned out to be nothing but a bunch of bubbles to be burst one after the other once setting foot on the American soil. It says: 
On her journey she cooed to the swan: "In America I will have a daughter just like me. But over there nobody will say her worth is measured by the loudness of her husband's belch. Over there nobody will look down on her, because I will make her speak only perfect American English. And over there she will always be too full to swallow any sorrow! She will know my meaning, because I will give her this swan - a creature that became more than what was hoped for."

But when she arrived in the new country, the immigration officials pulled her swan away from her, leaving the woman fluttering her arms and with only one swan feather for a memory. And then she had to fill out so many forms she forgot why she had come and what she had left behind. [21, pp. 4-5]

As a symbol, swan in this tale carries different implications worth noting. In Chinese mythology, to begin with, it symbolizes the male principle in the yin-yang theory [3, p. 698], which is ironically taken away from the character, leaving her unsettled given the disturbed balance between the complementary forces of yin and yang. What remains of the swan after this displacement is only a feather to serve as a "memory" to cling on. That is, all the fanciful wishes and hopes for a better life are plucked off the beautiful bird in the new world and the immigrant subject is left wondering what to do with the only remnant of her once "good intentions," being a feather of no obvious use and import. Having raised her daughter to speak "perfect English," she has even lost the chance to establish a genuine communication with her, lacking the required linguistic competence in English. Again ironically, her ultimate wish that one day her daughter would "know [her] meaning" and appreciate what she had done for her is not fulfilled either, because as she notices, not only does the daughter speak a different language, she also displays a different culture having been raised in a consumerist society saturated by "Coca Cola" commodities. No wonder, then, why she feels all the more dejected and miserable in the new land, disillusioned with all the myths it once promised. It is also implied that she herself has turned into a swan dispossessed of her dreams and the ability to fly back (in time or space) to where and "what she had left behind" [21, p. 5]. This bleak picture of the precarious life of a disillusioned Chinese immigrant woman in the American society should be taken as the critical backdrop of the whole story and not as a separate tale placed outside it.

\subsection{Untenable Binaries: Daughters $\Leftrightarrow$ Mothers.}

As reviewed earlier, many critics have asserted that Tan's portrayal of daughter/mother relationship in the novel is structured over a series of (Orientalist) binary oppositions such as American individualism/Chinese communality, American modernity/ Chinese tradition, etc. Yet, this kind of clear-cut classification of us and them fails to do justice to the complex dynamics of cultural negotiations occurring in every encounter established between two subjects of different cultural backgrounds. Chineseness or Americanness is not so much an essential entity as it is a construct of the discourses in which it is placed in oppositional relationship to "others." Thus, it would be futile to make the characters fit into these binarist hierarchies, thereby depriving them of their agency and power to adopt or resist the dominant discourses.

Feminism, for example, is one of the main zones of cultural conflict over different perceptions of women's rights in multi-ethnic American novels. In Tan's novel too, it constitutes one of the major preoccupations of the story revolving around both groups of mothers and daughters with the latter veering more readily to assimilation. Still, it does not mean that the mothers are not affected by it or that the daughters' integration into American feminism brings them any particular privileges denied the mothers. On the contrary, as the story of each individual daughter reveals, the feminism they had adopted has done little to make them any stronger than their alleged traditional mothers in facing the problems in life, with almost all ending up in failed relationships, unfinished degrees, and botched jobs. June, the predominant storyteller of the novel, for instance, is "a failure, a "college drop-off"," with no specific goals in her life until she is set one by her late mother to search for her half sisters in China [21, p. 22]. The biggest achievement she has been able to make is working "as a copywriter for a small ad agency" [21, p. 155] with low wages. Ironically, the only thing which gives her a sense of center and orientation is a jade pendant her mother, Suyuan, gives her as a reminder of her "life's importance" [21, p. 164]. She comes to 
understand the worth of this act sometime after he mother is dead, when there is nothing else to hold on to but a genuine matrilineal bond symbolized in the pendant. The following passage details June's reception of the article both before and after her mother's death:

Five months ago ... my mother gave me my "life's importance," a jade pendant on a gold chain. The pendant was not a piece of jewelry I would have chosen for myself ... To me, the whole effect looked wrong: too large, too green, too garishly ornate. I stuffed the necklace in my lacquer box and forgot about it. But these days, I think about my life's importance. I wonder what it means ... And she's the only person I could have asked, to tell me about life's importance, to help me understand my grief. I now wear that pendant every day. I think the carvings mean something. [21, p. 154]

Of all the daughters depicted in the story, this is only June who manages to appreciate and embrace her Chinese background instead of fleeing from it. Nevertheless, other girls admit to their distinctive ineptitude and incompetence compared to their powerful and adept mothers, especially at the time of crises. Lena St. Clare, who is getting divorced from Harold, her American husband, remembers how her mother objected to her marriage in the first place and now that she is trying to keep her in dark about their crumbling relationship, she feels that her mother, Ying-ying, already knows it, having the ability to foretell future through her enigmatic skill of reading the signs of what is to come. She says: "To this day, I believe my mother has the mysterious ability to see things before they happen" [21, p. 111]. Even when stuck in cross-cultural moments of misunderstanding, the daughters know that their mothers prove to be better hearers and more understanding than they are. In retrospect, June, for example, remembers how her mother had a better ear for understanding her "American" language. She says: "We translated each other's meanings and I seemed to hear less than what was said, while my mother heard more" [21, p. 22]. Yet, inflected by the Orientalist discourses, daughters attribute this strength to some invisible Chinese essence which they lack but their mothers possess. That is, they fail to understand it beyond the exoticized representations of the Chinese culture. Thus, on a deeper level, the depiction of the same Americanized daughters for whom Tan has been praised or criticized, do not constitute a homogenous identity, nor can they be hailed as any more successful than their supposedly backwarded Chinese mothers.

\subsection{Subaltern Resilenced.}

The novel abounds with stories about daughters' assimilationist aspirations and the disillusioning consequences befalling them. Rose, An-mei's daughter, for instance, relates that the reason why she fell for Ted at the college was "precisely the things that made him different from my brothers and the Chinese boys I had dated; ... the fact that his parents immigrated from Tarrytown, New York, not Tientsin, China" [21, p. 86]. Disregarding her mothers' warning that he is a "waigoren," [21, p. 87] meaning foreigner, she continues to date him until one day Ted introduces her to his family and it is there that she realizes how she is treated as a subhuman "foreigner" no matter what. Ted's mother, mistaking her for a Vietnamese, tacitly shows her discontent with the prospect of her son marrying a girl from "minorities" [21, pp. 86-87]. With the son's persistence, they finally get married, but Rose unconsciously takes up playing the role of helpless victim to be rescued by her American hero. She says: "Ted decided where we went on vacation. He decided what new furniture we should buy. ... We used to discuss some of these matters, but we both knew the question would boil down to my saying, 'Ted, you decide"' [21, p. 88]. This happy romance of man's chivalric heroism and woman's inert passivism comes to a sudden halt when Ted grows tired of the game. Having turned into a mindless stereotype, Rose is left at a loss when Ted refrains from shouldering the usual responsibilities in their life. Poking fun at her lack of agency, one day Ted asks her if she married him just because "the minister" wanted her to repeat after him. He says: "How the hell did we ever get married? Did you just say 'I do' because the minister said 'repeat after me'?" [21, p. 89]. This crumbling slave/master relationship betokens the precarious state of all assimilationist characters like Rose who mould themselves into imagined roles and stereotypes such as that of the Oriental woman as an oppressed victim to be rescued (unveiled, civilized, Americanized) by the West. It also testifies to the assimilationist characters' internalized sense of inferiority in relation to Americans. Deeming themselves 
undeserving of any privileges allotted to their American counterparts, they barely stand up for their equal rights in life. After her divorce, Rose seems to have gained some insight into this problem. She says: "At first I thought it was because I was raised with all this Chinese humility, ... Or that maybe it was because when you're Chinese you're supposed to accept everything, flow with the Tao and not make waves. But my therapist said, Why do you blame your culture, your ethnicity?" [21, pp. 117-118]. And, we hear this from Lena's lips, who is grappling with the same problem in her relationship with Harold, another American guy. Suffering from the same inferiority anxieties, Lena relates that she never saw herself deserving the love of an American. She says: "All I can remember is how awfully lucky I felt, and consequently how worried I was that all this undeserved good fortune would someday slip away. When I fantasized about moving in with him, I also dredged up my deepest fears: that he would tell me I smelled bad, that I had terrible bathroom habits, that my taste in music and television was appalling" [21, p. 117]. From Lena's essentialist stance, Chineseness designates every despicable thing Americans lack including humility, passivity, bad smell, and unattractive looks.

\subsection{Difference Disavowed: Biological and Cultural.}

The feminism adopted and practiced by these daughters is subliminally exposed as failing to recognize the Chinese-American's special positioning as coming from a different cultural background, hence denying them the right to be any different from "us," culturally or even biologically. The latter issue is most poignantly evidenced in the daughters' discontent with their looking like their mothers in terms of facial complexion. When Waverly takes her mother to an American saloon, the hairdresser expresses his sense of wonder at how "uncannily" they look alike [21, p. 200]. Waverly's "eyes and her smile become very narrow, the way a cat pulls itself small just before it bites" [21, p. 200]. In Waverly's view, it is fine to look Chinese only when it becomes fashionable so that she can take advantage of her exotic value in her encounters with the American.

Feministic espousal of women's economic independence and equality in a given relationship with a male partner is also subtly contested in Lena's "modernized" conjugal life with Harold. When Lena's mother pays a visit to their home, she runs across a "shop list," [21, p. 121] stuck on their refrigerator in which the things they had bought and how much they had cost are divided in two separate columns: Lena's and Harold's. When she confronts her daughter with it, Lena thinks to herself: "So we can eliminate false dependencies ... be equals ... love without obligation" [21, p. 123]. Finding the ritual as a sign of malfunctioning relationship, the mother, however, has a totally different interpretation: "All around this house I see the signs. My daughter looks but does not see. This is a house that will break into pieces" [21, p. 190]. She knows that equality in relationship is not a statistical fact to be measured and kept in balance by some quantifiable mathematic formulae. As architects, ironically, what they are doing to their marital life is like "draw[ing] fancy buildings and then live in one that is useless" [21, p. 190]. That is, this feminist understanding of love, woman's independence, and equality, as practiced by Lena and Harold, proves to be good only in theory and not in practice as it fails to take into account the immaterial dimensions of a given relationship between man and woman as two human beings with far more important needs and desires than economic dependencies. Ironically, this is Rose's mother who urges her not to easily give up on her rights when Ted resolves to divorce her despite her unwillingness. When Ted sends her divorce papers to be signed and returned, Rose realizes that he had claimed all the properties for himself hoping that she would mindlessly give in without showing any objection. Prompted by her mother to stand up for herself, this time however, Rose does not act out the role of the submissive oriental wife, hence resisting his further exploitations. Finally confronting him for once and all, Rose, grown out of the imposed image of the muted subaltern, declares that: "You can't just pull me out of your life and throw me away" [21, p. 153]. Adams, also, in passing, refers to Tan's "critique" of American patriarchy along with the Chinese one. She notes that: "The white American patriarch may seem like the 'big, important husband' or the 'angel of light', rescuing Chinese and Chinese American women from Chineseness, but the benevolence of this paternal act is revealed for its racial and imperial underpinnings when rescued women are subordinated, even in the USA" [1, p. $126]$. 


\subsection{Mothers as Chinese Scheherazades: Storytelling and Survival.}

Except for June who manages to step outside the discursive constrains of American culture and appreciate her Chinese culture too, the daughters in this story tend to fashion a purely American identity for themselves which as explained earlier leaves them all the more confused and lost, especially in their failed encounters with Americans who would ultimately see them as nothing more than exotic fetishes to enjoy. The mothers, however, prove to have a better understanding of the workings of culture in the ongoing process of identity-construction. Interestingly enough, they are good storytellers too and the stories they tell never end up the same. That is, they keep changing the endings every time they tell an old story. This ever-changing quality bears witness to their appreciation of life as an ongoing narrative full of possibilities with no predictable closures, hence their leaving the stories open to future revisions. It can also be interpreted as a survival mechanism mothers use not to lose their grip on the reality. In this sense, they become the Scheherazades of the embattled Chinese-Americans, struggling to fend off the threats faced with in the new society. And if they continue to change the stories every time they tell them it is suggestive of the fact that they are still struggling with more and more challenges in the American society to survive. Talking about how her mother's story of survival kept growing, June says: "she began to roll with one sweeping rhythm, she would start her story. Over the years, she told me the same story, except for the ending, which grew darker, casting long shadows into her life, and eventually into mine" [21, p. 7]. Somewhere else, she adds: "I never thought my mother's Kweilin story was anything but a Chinese fairy tale. The endings always changed. ... The story always grew and grew" [21, p. 11].

\subsection{Chess Games; American Rules of Culture.}

Mothers also seem to have a better grasp of their positioning in between cultures and the possibilities it endows them with. As in chess games, a leitmotif of the novel, cultures have their own rules. A foreigner likewise should learn the rules before he can enter the game. Waverly's mother likens the rules of playing chess to those of American culture:

This American rules ... Every time people come out from foreign country, must know rules.

You not know, judge say, Too bad, go back. They not telling you why so you can use their way

go forward. They say, Don't know why, you find out yourself. But they knowing all the time.

Better you take it, find out why yourself. [21, p. 67]

Culture, in his sense, is not viewed as an essential entity to be passed down from generation to generation. However, it is deemed a set of arbitrary man-made rules to which people subscribe in a given community and as such leave out those who do not belong (racially) or fail to practice them (culturally) fully. That is, every given culture is as much about identification and unification of different individuals in the form of (imagined) communities of a shared collective identity as about disavowing and excluding those it views as foreigners or others.

This awareness helps Lindo, Waverly's mother, to use the rules in her own interest in different situations. For instance, at the barber's, when Mr. Rory, the American hairdresser speaks past Lindo to her daughter as if he does not see her, she uses an indifferent soulless "American face," smiling so as not to show her irritation [21, p. 200]. And interestingly enough, she is selfconscious that this fake face is what Americans wish to attribute to the Chinese and see it on their faces. She thinks to herself: "I smile. I use my American face. That's the face Americans think is Chinese, the one they cannot understand. But inside I am becoming ashamed" [21, p. 200]. This double-facedness, then, is not an essentially Chinese quality as is advocated in Orientalist discourse. However, in the new community, they often find themselves obliged to do it out of necessity so as to comply with the rules of the game. Recounting the story of her immigration to the US and the troubles she had been through before learning the rules, Lindo tells her daughter that even before arriving in the US, she had to meet and pay "an American-raised Chinese girl in Peking to show [her] how to" pass off as someone she is not but Americans approve of [21, p. 202]. The following passage contains some critical points about American culture worth noting:

"In America," she said, "you cannot say you want to live there forever. If you are Chinese, you must say you admire their schools, their ways of thinking. You must say you want to be a scholar and come back to teach Chinese people what you have learned.” ... 
"Be careful, though," she said. "The authorities there will ask you if you have children now or if you are thinking of having some. You must say no. You should look sincere and say you are not married, you are religious, you know it is wrong to have a baby."

I must have looked puzzled, because she explained further: "Look here now, how can an unborn baby know what it is not supposed to do? And once it has arrived, it is an American citizen and can do anything it wants. ..."

But that is not the reason I was puzzled. I wondered why she said I should look sincere. How could I look any other way when telling the truth? [21, pp. 202-203]

To Lindo, the distinction between looking sincere and being sincere sounds fallacious for she cannot tease them apart. Thus, hypocrisy and double-facedness arise out of necessity in the new society in which you cannot be who you are, or else to which you are not even allowed. From this contrapuntal point of view, it is part of the American rules, and not Chinese, to hide your true self behind fabricated masks of approvable and contained differences. Can we not also attribute the same internalized sense of Orientalism and compliance with the demands of the American readership, on the part of writers such as Tan herself, as an indicative of the same self-defense mechanism of survival?

\subsection{Reinscription of Orientalist Codes of Recognition.}

Lindo also reproaches her daughter for twisting the real account of her journey to the US into an authorized stereotypical story, hence reducing all varied and heterogeneous accounts into a simple and easy-to-circulate tale of arriving in the US "on a slow boat from China" [21, p. 203]. Ironically enough, what Lindo fails to perceive is that the way Waverly mystifies her mother's travel to the US as a Chinese immigrant is in keeping with the same rules she is trying to teach her daughter, the rule of reproduction of dominant discourse as a prerequisite for being credited as one of us, though not fully. That is, for the daughters to win the recognition of assimilability, something denied their parents who are fully Chinese, they are obliged to steer into the skid by taking up the role of native informants. As such, Lindo's criticism of her daughters' reinscription of Orientalized totalizations about Chinese experiences is in fact directed at the xenophobic discourses prevalent in the American society which are kept in circulation and to which a foreigner has to fully subscribe if he is to be taken "in the true," in Foucauldian sense [18, p. 58]. Lindo says:

Why do you always tell people that I met your father in the Cathay House, that I broke open a fortune cookie and it said I would marry a dark, handsome stranger, and that when I looked up, there he was, the waiter, your father. Why do you make this joke? This is not sincere. This was not true! Your father was not a waiter, I never ate in that restaurant. The Cathay House had a sign that said "Chinese Food," so only Americans went there before it was torn down. Now it is a McDonald's restaurant with a big Chinese sign that says mai dong lou-"wheat," "east," "building." All nonsense. Why are you attracted only to Chinese nonsense? You must understand my real circumstances, how I arrived, how I married, how I lost my Chinese face, why you are the way you are. [21, p. 203]

Why? Because it is a recognizable statement as to how the Chinese settled and made their fortunes in the US, occluding the historic specificities and contingencies involved. The image of a Chinese woman meeting her would-be husband by chance in an ethnic house in Chinatowns which function as landmark chronotopes in this genre is a replica of mass media account of Chinese immigrants' story of settlement in the US. Just like "breaking open a fortune cookie," in this sugarcoated story, the wandering Chinese immigrant arrives in the US, finds a job, and gets settled with a mate of his or her race. The "Cathay House" also carries implication of illicit activities such as opium trade, prostitution, and slumming which were rife in Chinatowns especially in the first half of the twentieth century, but as Chad Heap points out, they were ironically catered to the curious interests of the white American who regularly made excursions into these "foreign" districts so as to gratify their anxieties by projecting them upon the exotic, barbarian, and morally-wrong others [13, p. 19]. Thus, the Chinatowns were turned into safe zones for fulfillment of the otherwise forbidden desires suppressed in the civilized world of hypocrisies, hence the sign "Chinese Food" which is tellingly in English and appeals to the American audience [21, p. 203]. In other words, Chinatowns function as 
a simulated simulacrum or hyperreality, in Baudrillard's words [2, p. 81], with no original Chinese reality to refer to. It merely signifies an Americanized Chineseness fixated through such cliché exoticized signs as Chinese cuisine and, more tellingly "fortune cookies," which are served at Chinese restaurants all over the US as a treat after the meals without having any clear cultural origins [21, p. 203]. Oddly enough, when a merchant once decided to import this product into Chinese markets, he soon found out that fortune cookies were considered "too American" by the Chinese customers [17]. This is while in the US, it is sold and consumed for its exchange value as an exotic Chinese tradition, which being fabricated and untrue, from Lindo's point of view, as a subject positioned in the third space, is all "nonsense" [21, p. 203]. Interestingly enough, through McDonladization of the restaurant, it is said that the English sign was later one replaced with a Chinese one so that it would sound like a perfectly Chinese reality with no apparent links to the American consumerist forces constructing and maintaining it.

Another important preposition entailed in this tale is the emasculation of the Chinese male subject relegated to "womanly" professions such as laundry and restaurant work. As Cynthia Sauling Wong puts it, feminization and masculinization have always been two sides of the same coin used in marginalization of ethnic groups in the American society [23, p. 112]. In case of the Black, for instance, they are portrayed as being "abnormally libidinous and driven by aggressive sexual appetites," whereas the Chinese, male or female, are "skewed" toward the "female side" resulting in "the effeminization (which is also to say emasculation) of the Asian man and the ultrafeminization of the Asian woman" [23, p. 112]. Chin also considers emasculation as one of the major tools used in stereotypical representation of Chinese Americans: "Good or bad, the stereotypical Asian is nothing as a man. At worst, the Asian-American is contemptible because he is womanly, effeminate, devoid of all the traditionally masculine qualities of originality, daring, physical courage, and creativity" $[9$, p. 6].

\subsection{Chinese Myths Demystified.}

As the only character to have taken steps toward hybrid understanding of cultures, June makes a symbolic journey to China at the end of the story in order to meet her half sisters in her mother's place at the request of the aunties. It is in this chapter that June encounters Chinese people outside America, hence further demystification of her Orientalized perceptions of Chinese culture. Bewildered by the chasm she perceives between her Orientalized understanding of Chinese culture and what she has begun to appreciate as an equally compelling set of rules with its own complicated ins and outs, she admits that she has "never really known what it means to be Chinese" [21, p. 211]. Finding the people behaving just like Americans on a regular day at a regular train station, she forgets that she is in China and not in San Francisco [21, p. 214]. Or, when she meets Aiyi, her great-aunt, June does not find her looks any different from other elderly she had seen in the US, for she too looks old and shrunken with her hair grown white. This simple fact bewilders her as it runs counter to the myth that "Chinese women look young forever" [21, p. 217]. And as June tries to establish a dialogue with her, the only Cantonese words she is able to remember are "swear words, terms for bodily functions, and short phrases like 'tastes good,' 'tastes like garbage,' and 'she's really ugly,"' all inflected by the American consumerist culture [21, p. 217]. To her surprise though, the hotel she stays in during this trip turns out to be "a grander version of the Hyatt Regency" with all the regular signs of conspicuous consumption she may expect to see at a luxury hotel in the US [21, p. 219]. That is, the essentialist distinctions between Americanness and Chineseness begin to falter in her mind.

The symbolic reunion of June with her half sisters lost for decades contains another illuminating fact about China, namely its heterogonous population comprised of a wide variety of cultures, religions, and languages. June already knows how and why her mother was forced to leave her newly-born twins behind and run for her own life under the Japanese attacks on China in 1941. But she is eager to know how they were miraculously saved while everyone else had been busy saving their own lives running from the war. When she asks her great-aunt about it, she is told that they were found and raised by "pious people" a Muslim couple who took care of the kids like their own babies and that afterwards they had made every effort to reunite them with their true family 
[21, p. 225]. Describing the Muslim woman, Aiyi says: "She loved these girls so much, she only wanted them to have what they were entitled to - a better life, a fine house, [and] educated ways" [21, p. 225]. This seemingly minimal and simple subplot is a very good case in point for what Bhabha calls narratives of "freak displacements" which he urges to be placed at the center of world literature studies [5, p. 145]. Because it is in these displaced moments of absence of a fixed cultural identity and epistemological centricity that discursive fractures crop up. In here, Tan's portrayal of the Muslim couple as a kind-hearted, caring, and benevolent family tacitly challenges several common orientalist presuppositions at stake in mainstream media about Muslims portrayed as being unassimilable, unconstructive, and threatening to social integration and general peace of communities. Sadly, these negative stereotypes have come to accrue more factual status to themselves because of their constant reproduction within the neocolonial nexus of power relations in the wake of 9/11 terrorist events. Equally important is Tan's effective de-racialization of religions by including the Muslim family in the story, thereby resisting the exclusionary workings of the dominant discourses in assigning each religion to a particular race. For instance, in the mass media accounts, the Chinese are lumped together as Buddhist vegetarians or the Muslim as Arab Jihadists. Thus, the inclusion of the Chinese Muslims in the story not only challenges the totalizing mechanisms involved in consolidating the Orientals into a unified mass but also foregrounds the heterogeneity of every eastern community, including Chinese.

\section{CONCLUSION}

As discussed early on, Tan's The Joy Luck Club has been approached from two oppositional stances. On the one hand, it has been warmly received by both intelligentsia and popular readership as an embodiment of minority model myth and as a clear vindication of such dominant discourses as Orientalism, American feminism, multiculturalism, American dream, etc. [6, 21, 10]. On the other hand, it has been equally criticized by fellow Chinese-American critics and some other antiorientalist readers who found the book a replica of all the negative and "fake" stereotypes about Chinese people and their culture as originated in dominant American discourses [1, 9, 24]. From the latter perspective, Tan is deemed another native informant who had followed in the footsteps of her predecessors such as Pardee Lowe and Maxine Hong Kingston in adapting Chinese traditions of storytelling to American genres and adopting an apologetic style in writing about Chinese culture, hence reducing it to cliché codes of identification and representation appealing to the exoticizing gaze of the American publishers and readers. In this study, however, an in-between position was adopted in an attempt to bring to light those aspects of the novel which might have slipped the critical attention of the readers. In this approach, the third-space encounters arising from the peculiar positioning of the characters at crossroads of cultural perceptions are taken as points of departure in analyzing the ways discourses lose their grip upon the in-betweeners. In this process, the film of naturalness and originality is removed from the familiar and habitualized perceptions of reality in the eyes of the subject placed in the third space. Nevertheless, not all subjects are able to tackle the unanticipated results of this transformative process. That is why the majority of characters depicted in Tan's novel tend to forge either nativist or assimilationist, and not hybrid, identities. Still, both groups prove to have undergone certain changes in their encounters with the new or opposing worldviews. As for the discourses contested throughout the novel, American dream, American feminism, globalization, multiculturalism, and more importantly, Orientalism receive the major blows. The illusion of being able to become whatever you wish in the US, social mobility, impracticality of homogenizing feminist conceptions of women and the feminists' failure to recognize Oriental woman beyond the Orientalist representations, xenophobic renditions of ethnic minorities, American patriarchy, consumerist culture, simulacrum of Chineseness in Chinatowns, stereotypical identifications of the Chinese in everyday encounters within American society, exotic fetishism of cultural difference, emasculation of Chinese male subjects, and essentialization of us and them around hierarchical binary oppositions of modernity/tradition, individual/mass, rebellion/ conformity, male/female, civilization/barbarity, master/slave, etc. are some of the main issues addressed and challenged in this story on different levels. 


\section{References}

[1] B. Adams, Asian American Literature, Edinburgh U P, Edinburgh, 2008.

[2] J. Baudrillard, Simulacra and Simulation, Michigan U P, Michigan, 1994.

[3] H. G. Baynes, Mythology of the Soul, Routledge, London and New York, 2015.

[4] H. K. Bhabha, The Location of Culture, Routledge, London, 1994.

[5] H. K. Bhabha, The world and the home, Social Text. 10.31-32 (1992) 141-53.

[6] H. Bloom, (Ed.), Asian-American Writers, Infobase, New York, 2009.

[7] H. Bloom, The Anxiety of Influence: A Theory of Poetry. Oxford U P, Oxford, 1997.

[8] Y. Chae, Politicizing Asian American Literature: Towards a Critical Multiculturalism, Taylor \& Francis e-Library, New York, 2007.

[9] K. Cheung, Words Matter, U of Hawai'i P, Honolulu, 2000.

[10] S. M. Darraj, Amy Tan, Infobase Publishing, New York, 2007.

[11] P. Duncan, Tell This Silence: Asian American Women Writers and the Politics of Speech, U of Iowa P, Iowa City, 2004.

[12] S. During, Cultural Studies: A Critical Introduction, Routledge, London and New York, 2005.

[13] Ch. Heap, Slumming; Sexual and Racial Encounters in American Nightlife, 1885-1940, U of Chicago P, Chicago, 2009.

[14] G. Huggan, The Postcolonial Exotic, Taylor \& Francis e-Library, New York, 2003.

[15] F. Kral, Critical Identities in Contemporary Anglophone Diasporic Literature, Palgrave Macmillan, New York, 2009.

[16] N. Lucy, A Derrida Dictionary, John Wiley \& Sons, New Jersey, 2008.

[17] B. Mikkelson. Inscrutable cookie, Snopes. (2015). Information on http://www.snopes.com/food/origins/fortune.asp

[18] S. Mills, Michel Foucault, Routledge, London, 2005.

[19] O. Schell, Your mother is in your bones, New Yorker Times. (1989). Information on https://www.nytimes.com/books/01/02/18/specials/tan-joy.html

[20] E. Said, Consolidated vision, in M. Bal (Ed.), Narrative Theory, Routledge, London and New York, 2004, pp. 69.87.

[21] A. Tan, The Joy Luck Club, Putnam's, California, 1989.

[22] E. J. Teng, Chinese diasporic literature, in Ch. A. Laughlin (Ed.), Contested Maternities in Chinese Literature, Palgrave McMillan, New York, 2005, pp. 61-80.

[23] S. C. Wong, Reading Asian American Literature: from Necessity to Extravagance, Princeton U P, Princeton, 1993.

[24] J. Yin, Constructing the other: a critical reading of The Joy Luck Club, The Howard J. of Communications. 16 (2005) 149-175. 